\title{
THE USE OF SPEECH ACTS IN ANGNGARU OF MAKASSAR SOCIETY
}

\author{
Murni Mahmud \\ English Education Department, Faculty of Languages and Literature, Universitas Negeri Makassar \\ Jalan Daeng Tata Raya, Kampus Parangtambung, Makassar, Indonesia \\ email: murnimahmud@unm.ac.id
}

Article History:
Submitted: 6 May 2019; Revised: 22 June 2019; Accepted: 8 July 2019
DOI: 10.26858/retorika.v12i2.9099
RETORIKA: Jurnal Bahasa, Sastra dan Pengajarannya under license of
Creative Commons Attribution-NonCommercial 4.0 International License.
ISSN: 2614-2716 (print), ISSN: 2301-4768 (online)
http://ojs.unm.ac.id/retorika

\begin{abstract}
The Use of Speech Acts in Angngaru of Makassar Society. The objective of this research is to explore the use of speech acts in Angngaru. Through the framework of speech act Searle (1969), this paper focuses on exploring the types and functions of Angngaru in Makassar society. To gain data, Angngaru texts were collected and analyzed through the techniques of discourse analysis. To support the data analysis, some performances of Angngaru were observed. The performers of Angngaru were also interviewed. The results of the study show that Angngaru has important roles in Makassar society. The types of speech acts were found in Angngaru such as representatives, directives, commissives, and expressives. The analysis of the types and functions in this language use remars the strong relationship between language and culture in a particular society.
\end{abstract}

Keywords: language, culture, speech acts, Angngaru, Makassar society

Abstrak: Penggunaan Tindak Tutur pada Angngaru dalam Masyarakat Makassar. Penelitian ini bertujuan mengeksplorasi penggunaan tindak tutur di Angngaru. Melalui kerangka analisis tindak tutur Searle (1969), penelitian ini berfokus pada eksplorasi jenis dan fungsi Angngaru dalam masyarakat Makassar. Untuk mendapatkan data, teks-teks Angngaru dikumpulkan dan dianalisis melalui teknik analisis wacana. Untuk mendukung analisis data, beberapa pertunjukan Angngaru diamati. Para pemain Angngaru juga diwawancarai. Hasil penelitian menunjukkan bahwa Angngaru memiliki peran penting dalam masyarakat Makassar. Sebagai bagian dari kehidupan budaya, Angngaru digunakan untuk mengekspresikan penghargaan dan rasa hormat. Jenis tindak tutur yang ditemukan di Angngaru, yakni representatif, direktif, komissif, dan ekspresif. Analisis jenis dan fungsi dalam penggunaan bahasa ini menunjukkan adanya hubungan yang kuat antara bahasa dan budaya dalam suatu masyarakat tertentu.

Kata kunci: bahasa, budaya, tindak tutur, Angngaru, masyarakat Makassar 
Studies in terms of language and communication remain essential in today's society. Studies on the communication function had flourished and proved that communication strategies are needed to overcome the problems in communication. One of the examples of those studies is in terms of classroom interaction (Pawlak, 2015; Chang \& Liu, 2016; Mahmud, 2017; Krishnan, Ramalingam, Ching, \& Maruthai, 2018). These studies show that the communication strategies are helpful in solving the communication problems encountered by the teachers and students in the learning process in the class and in creating effective classroom interaction. This fact shows that language has an important function to maintain good interaction in one community. Failure in using language to communicate can result in a failure of interaction.

The function of language is not only, however, as a means of communication. It is also a symbol of the identity of the language users. Mesthrie (2000:6) had argued that language is not just "denotational, referring to the process of conveying meaning or referring to ideas", but also it is "indexical" in which language is "a symbol of one's social class, status, region of origin, gender, age group, and so on". This means that what is going on in a particular society can be seen in the language people speak. This is confirmed by Levi-Straus who said that "to say language is to say society" (cited in Duranti 1997:337). Therefore, it can be stated that language is not only used to communicate ideas and information but also to symbolize one particular society or as a symbol of one community.

This fact shows that what is in one community can be revealed through the language they used. Sifianou (1992:12) argued that "the relationship of the interactants, age, the specific situation, and so on, will directly affect their language use to degrees determined by the culture". In the same line, Kramsch (1998) stated that there is a strong connection between language and community because it is through "the accent, vocabulary, discourse patterns, speakers can identify themselves and be identified as members of the community". Kramsch further stressed that language "expresses, embodies, and symbolizes cultural reality". These ideas confirm that there is a strong relationship between language and culture in one particular society.

Indonesia as a country of various languages and culture offers a lot of opportunities for language and cultural studies. One of the communities which attract the interest of anthropologists and sociolinguists is Makassar society (Chabot, 1996; Wahid, 2008; Iswary, 2009). Chabot (1996), for example, studied about kinship and status. Wahid (2008) explained the social system of Makassar people whereas Iswary (2009) had examined the teaching of ethics in relation to local Makassar belief.

Makassar is usually recognized as one ethnic group located in several regencies in South Sulawesi. It also means the name of one Kingdoms, named Gowa in the sixteenth century (Iswary, 2009:99). Nowadays, Makassar is known as the capital city of South Sulawesi, one province located in the Eastern part of Indonesia, which was previously known as Ujung Pandang.

Makassar people are rich with cultural norms. The possession of siri' na pacce (shame and compassion) is a philosophy embodied in their life. This philosophy regards the importance of mutual understanding in Makassar life. Siri' is the feeling of being "ashamed, diffident, shy, shame, sense of honour, disgrace" (Matthes cited in Graham, 2001:2) whereas pacce may mean to "feel pain for somebody else in one's stomach, indicating a feeling of compassion for one's neighbor, relative or fellow member of a social group" (Yatim as cited in Pelras, 1996:208). In addition, Makassar people have basic principles of mutual understanding as expressed in the concept of sipakatau (respecting each other as people), sipakalakbirik (respecting people regardless of any differences), sipassiriki (preserving honor each other), sikalaibine (being together), sialle (being one in a family), and sisarikbattang (being siblings together). The concept of sulapak appak (square) is also important which showed the characteristics of Makassar people, namely barani (brave), lambusuq (honest), caraqdeq (smart), and kalumanynyang (rich) (Iswary, 2009: 103-104).

Regardless of those facts, studies in terms of language use and cultural life in Makassar society had not been observed closely. There are very limited studies found in terms of language usage such as the study of Makassar language and expressions in communicative situations. For that purpose, this paper is directed to explore one function of language use to communicate in relation to the cultural aspects of Makassar society. This paper discusses a study of Makassar society in terms of their language use in one communi- 
cative situation, namely the use of Angngaru in Makassar society.

The word Angngaru comes from the Makassar language aru which means "promise". Angngaru here is meant as a loyal promise addressed to people in Gowa Kingdom in the past times. Previously, aru was a promise between the King and autonomic government covering the restricted agreement between the King with other authoritative rulers. In the past times in the Gowa Kingdom, the King rulers who were appointed were required to pronounce the promises in front of the King that they would do their duties properly. This promising act functioned as a motivation to reach the expectations of the King in managing the Kingdom. Besides, the soldiers who went to war at the time were required to promise in front of the King that they would defend the Kingdom, defend the rights, and never surrendered (Limpo, Culla, \& Tika, 1995; Gunawan, 2013; Khairuddin, 2014). Nowadays, Angngaru is usually used as a part of ceremonies in Makassar society, such as in wedding parties. It is also performed in some formal events such as in the welcoming ceremonies in seminars, meetings, and so on.

The fact above shows that Angngaru as a form of promising expressions for Makassar people is worthy of exploration. Through the framework of speech act analysis, as a form of language use, this study suggests an intensive investigation of language use in particular society influenced by the cultural life of the people. There are two main questions brought into discussion in this paper. The first one is "what are the speech acts used in Angngaru?". The second one is "what are the functions of Angngaru in Makassar society revealed through the use of speech acts?" Findings from this study are precious especially in the field of sociolinguistics and linguistic anthropology. Results are also beneficial in the literature of Makassar culture and society, one of the predominant ethnic groups in South Sulawesi, Eastern Indonesia and also in the literature of language and communication as a whole.

Discussion on speech acts is important as a way of doing something. Through speech acts, speakers choose ways of expressing themselves based on their objectives toward their hearers such as to believe, accept, or do something. Bonvillain (1993:101) noted that "the notion of speech act entails the fact that through speaking, a person accomplishes goals". Hymes also suggested the important function of the speech act in analyzing communication in a particular society. Hymes said that an act is generally "coterminous with a single interactional function, such as a referential statement, a request, or a command, and may be either verbal or nonverbal" (cited in Saville-Troike, 1982:28-30).

In studying language and communication, the forms of speech acts are influential. Two important linguistic philosophers, Austin (1962) and Searle (1969) had promoted the significant functions of speech acts in communication. Both of them proposed a taxonomy of speech acts with the main focus is "to perform actions". In addition, the fundamental insights of using speech acts are on "how meaning and action are related to language" (cited in Schriffin, 1994:49). Searle (1969, cited in Schriffin, 1994:54) had stated that the speech act is "the basic unit of communication" and therefore, it becomes "the center of the study of language, meaning, and communication".

A speech act, according to Austin (1962: 109), implied that "someone saying something is normally also doing something". Austin further differentiated three types of acts: (1) a locutionnary act which contains "a certain sense and reference" and is "equivalent to the real meaning", (2) an illocutionary act which has "a certain conventional force" or a "contextual function", and (3) a perlocutionary act indicating the effect on the addressee which "we bring about or achieve by saying something" (1962:109).

Another linguist, Searle (1969), proposed five classes of speech acts: (1) representatives (e.g. asserting, concluding), which commits the speaker to the truth of the expressed proposition, (2) directives (e.g. requesting, questioning), which are attempts by the speaker to get the addressee to do something or to direct someone towards some goals of the speakers, (3) commissives (e.g. promising, threatening, offering), which commit the speaker to some future course of action, (4) expressives (e.g. thanking, apologizing, welcoming, congratulating), which express a psychological state and express the inner state of the speaker, and (5) declarations (e.g. appointing, excommunicating, declaring), which affect immediate changes in the institutional state of affairs and which tend to rely on elaborate extra-linguistic institutions (cited in Schriffin, 1994:57; Levinson, 1983:240; Mey, 1993:163167). 
Batch and Harnish (1979:39-57) also developed a taxonomy of speech acts. The first one is constatives, which is used in expressing the speakers' belief and his intention or desire that the hearers have alike belief, such as asserting, predicting, describing, informing, responding, and suggesting. The second type is classified as directives, used to express the speakers' attitude toward some prospective action by the hearer and his intention that his utterance is taken as a reason for the hearer action. The directive expressions can be in the form of requests, questions, requirements, prohibitions, permission, and advice. Next is known as commissive, which is an utterance to express obligations by the speakers, which can be in the form of promising and vowing. Another type is acknowledgments, mainly dealing with feelings, such as apologizing, expressing condolence, congratulations, greetings, thanks, accept and reject. The last one is didactives, which is mostly used in teaching, for example, giving corrections, repetition, and evaluation.

Consequently, deep investigation and analysis on speech acts may serve as invaluable input on studying about one particular language of one society. Research studies on speech acts have been continuing and becoming the attention of scholars in many different areas of language studies. One example of study in terms of speech acts had been conducted in Arabic language by Al-Shboul and Maros (2013). By exploring the use of condolence in Jordanian Arabic language, they found that strategies of condolence were affiliated to faith and religious belief. Another study on speech act had also been conducted by Sattar, Lah, and Suleiman (2011) in the specific use of refusal strategies. They found that the refusal strategies as a part of speech acts in the Malaysian context were influenced by Malaysian culture.

In Indonesia, studies in these issues had also been flourished in several contexts of communicative situation. A study by Wajdi (2009) in classroom settings, for example, found many types of speech acts used by the teacher and the students and confirmed the strong power of speech acts in the class especially by the teacher. Another study in terms of classroom interaction was by Milal (2011) who found the function of directive speech acts as one indicator of power in the classroom. Other studies by Boxer, (2003), Upadhyay (2003), Syahri (2010), and Stranovska,
Fraternova, Munkova, \& Muglova, (2012) were successful on exploring speech acts in relation to polite expressions. In addition, studies between the use of speech acts and gender differences were also highlighted by some scholars (Amarien, 2010; Sari, 2010). All of these studies show that exploration of speech acts is precious and offers a deep investigation of language use in a particular communicative situation.

\section{METHODS}

This is a descriptive qualitative study with the focus of analyzing the use of speech acts in Angngaru. To gain data on the types of speech acts, the researcher collected the texts of Angngaru that had been recorded and transcribed from the performers of Angngaru. One of the reliable resources is the texts of Angngaru collected and transcribed from Maksud Dg. Siga, one of the prominent performers of Angngaru, which was entitled Aru Tubarania ri Gowa "The Promises of the Brave King of Gowa". These texts had been written in several sources (Limpo, Culla, \& Tika, 1995; Gunawan, 2013; Khairuddin, 2014). These texts are used continuously by any other performers on different occasions. For this study, the researcher took these existing resources which were still in the original language, Makassar. The texts were then translated into English by the researcher with the assistance of the native speakers of Makassar language (see appendix).

To support data on the functions of Angngaru in Makassar society, the performances of Angngaru in particular situations such as in the opening ceremonies of seminars were observed. An informal interview was also conducted with one traditional performance group known as Sanggar Seni "Traditional Art Community", located in Gowa District. This group served some Makassar traditional performances including Angngaru. To know the functions of Angngaru in Makassar culture, three informants were interviewed informally. One was H. Bahtiar Dg Sanre, 61 years), in Bontosunggu, one district in Gowa regency, the owner of the Sanggar Seni "Traditional Art Community", Rukanti, 50 years old, and also an interview with Arif, a student at the Faculty of Languages and Literature of the State University of Makassar, who usually performed Angngaru in some ceremonies within the 
university. The interview was conducted informally and notes were taken from it. The data elicited from this interview were used to explore the functions of Angngaru in Makassar society, as supporting data for analysis on the collected texts.

Discourse Analysis was used in this paper to analyze the data. Steps in doing Discourse Analysis were applied in this research, namely collecting texts, transcribing, translating, identifying, interpreting, and reporting the results. In this study, texts of Angngaru were collected and transcribed. Since the texts were in Makassar language, those texts were translated first into English. Next, the texts were identified to find out the speech acts under the framework of Searle's speech acts (1969), which were then interpreted in terms of cultural functions in Makassar society. The final step was reporting the analysis in the forms of extracts.

\section{FINDINGS AND DISCUSSION}

\section{Findings}

One of the performances of Angngaru in one of the formal occasions, an international seminar hosted by the State University of Makassar, was observed. It was the opening ceremony of the seminar conducted at the hall of the Graduate Program of the State University of Makassar. On the right side, there were some performers equipped with their suling (traditional flute) and gendang (traditional drum). A young gentleman was coming forward with his red Makassar traditional costume. With his stuttering body, he pulled his badik (Makassar traditional weapon) and pronounced some expressions loudly with high intonation. He pronounced as follows:

\author{
Inakke minne, Karaeng \\ Here I am, the Lord \\ Lambara' tatassa'la'na Gowa \\ The hero from Gowa \\ Nakareppekangi sallang, Karaeng \\ Panngulu ri barugaya \\ Will break later, the Lord \\ The tip of my weapon in the arena \\ Pasorang attannga parang \\ Will break later the handle of the lance in the \\ middle of the battlefield
}

That was known as Angngaru. Arif, the performer, 22 years old, with his loud and strict sound pronounced Angngaru accompanied by his badik. That lasted for less than 5 minutes and after that one dance from some girls ended the ceremony. The girls performed the Makassar traditional dance, tari pa'duppa (welcoming dance). This dance was meant to welcome the guests, and in that seminar, the dance was meant to welcome all of the participants in the seminar especially those who hold positions in the university or other respected guests. When pronouncing the texts above, he stuck the badik on the floor showing that he really promised to do his best. His body was stuttering with a serious face and high intonation. As expressed in the Angngaru text above, the sentences he pronounced showed that he had promised to the King. He was the one who would break the weapon in the war and would not lose in the war. Since it was pronounced in the welcoming ceremony of the seminar, the promises in his Angngaru showed his promises to do the best for the coming event and made the seminar successful.

Based on the interview with Arif, it was found the sacred functions of Angngaru on that particular occasion. Arif said that there were three functions of Angngaru. The first one was previously used as a promise by soldiers who wanted to go in a war. Secondly, it was used to welcome the King's important guests. The third, it is now used in important and official occasions as a kind of appreciation and respect, especially in today's Makassar occasions.

Rukanti (50 years old), the owner of sanggar seni (traditional art community) and the other informant, H. Bahtiar Dg Sanre, 61 years), in Bontosunggu, one district in Gowa District, also confirmed that the performances of Angngaru nowadays is to welcome the guests to show appreciation, respect, and honor in one particular occasion. According to the informants, these Angngaru performances were important to preserve the Makassar traditions and cultural life among the present advances of technology.

The texts pronounced in Angngaru were rich in expressions. Some examples of speech act in the texts can be seen in the following extracts:

Extract 1:

Akkanamak numammio

I said, you confirmed 
Extract 1 above shows the use of representative speech act. In the above extract, the expressions show that the speaker tried to get "the addressee to do something or to direct someone towards some goals of the speakers" as expressed in "Akkanamak numammio" (I said, you heard). The speaker wanted to say and others listened to what he said. This is a kind of representative speech act, which aimed to commit the speaker to the truth of his expression. Other examples of representative speech acts can be seen in the following extracts:

\author{
Extract 2: \\ Ikau anging, Karaeng \\ You are like the wind, the Lord \\ Naikambe lekok kayu \\ I am like the leaves \\ Mirikko anging \\ Blow the wind \\ Namarunang lekok kayu \\ I am willing to go away with you \\ Iya sani madidiyaji nurunang \\ Although those of the yellow leaves had been \\ destroyed
}

In extract 2 above, the speaker asserted metaphors of the wind and the leaves in the expression "Ikau anging, Karaeng, Naikambe lekok kayu" (You are like the wind, the Lord, I am like the leaves). In this way, the speaker committed himself to the actions as though "he was the wind and the King was the leaves". This act tried to "commit the speaker to the truth of the expressed proposition". This is a kind of representative speech acts. The speaker represented himself was like the wind and the King was like the leaves. Other examples of metaphors can be seen in the following extracts:

Extract 3:

Ikau je'ne, Karaeng

You are like the water, the Lord

Naikambe batang mammayu

I am like the log of wood

Solongko jekne

Flow the water

Namammayu batang kayu

I am willing to drift with you

Iya sani sompo bonangpi na kianyu

Although at the rising tide we drift

Extract 4:

Ikau jarung, Karaeng

You are like the needle, the Lord

Naikambe bannang panjaik
I am like the thread

Takleko jarung

Break it through the needle

Namminawang bannang panjaik

Then I will follow and tie your footpath

In the above two extracts (extract 3 and 4), the speaker represented the actions by using metaphors of the water and the log of wood in the expression "Ikau je'ne, Karaeng, Naikambe batang mammayu" (You are like the water, the Lord, I am like the log of wood). The speaker also represented the action in the metaphors of the needle and thread expressed in "Ikau jarung, Karaeng, Naikambe bannang panjaik" (You are like the needle, the Lord, I am like the thread). These representations marked the representative roles of both the King and the servants. The expressions asserted that the King and the servants had their own roles that should be properly done. These representations can be categorized as a representative speech act. In addition, the expressions show the act of promising expressed in "Namammayu batang kayu" (I am willing to drift with you) and "Namminawang bannang panjaik" (Then I will follow and tie your footpath). These expressions are categorized as commissive speech acts. These types of speech acts can also be seen in another version of the text in extract 5 as follows:

\section{Extract 5: \\ Berangja kunipatekba \\ I am like the big knife ready to cut \\ Pangkuluk kunisoeang \\ The ax ready to swing \\ Ikatte anging, Karaeng \\ You are like the wind, the Lord \\ Naikambe batang mammayu \\ We are the leaves of the wood \\ Ikatte jarung, Karaeng \\ You are like the needle, the Lord \\ Naikambe bannang panjaik \\ We are the thread}

Like the previous three extracts, the speaker represented him as the big knife (berang), the ax (pangkulu), the leaves of the wood (batang mammayu), and the thread (bannang panjaik). These are the symbols of being loyal to the King. Those things are usually used by the servants to do their duties obliged by the King.

The second category of speech act observed in the texts is directives in the forms of re- 
quests and requirements. The speaker said in the following extract 6 and 7 :

\section{Extract 6:}

Anne niallenu kikaraengang

After being appointed as King

Teai panganuammang

Only our body who serves

Tanu alleai jangang ri leranna

Our rights are not like that

Tanukoccikiai bayao ribaka kampommang

You are not going to take chickens from the place they stay

Tanualleai kaluku sibatummang

You are not going to take our coconut or our palm fruit

Rappo sipaempan, punna niak nukaeroki panganuammang

If you want to have something from us

Nuballi sitaba nuballia

Buy those you can buy

Nusambei sitaba nusambeia

Change those you can change

Nupalaki sitaba nupalaka

Ask something that you deserve

Nakisareangko

And we will give it to you

In extract 6 above, the speaker maintained that in the position as the King, he will act as the servant. In doing the roles, the speaker said what the King should do and what he as the servant will do. The expressions in "Rappo sipaempan, punna niak nukaeroki panganuammang" (If you want to have something from us) and "Nakisareangko" (And we will give it to you) showed that what the King wanted would be fulfilled by the servant. There was a certain way of acting as a King and as a servant. This contains directive speech acts to lead the speaker to address some jobs to do for the hearer.

The third speech act is expressive in the forms of apologizing. Before pronouncing the promises, the speaker expressed his apologies that can be seen in the following two extracts:

Extract 7:

Bismillahirahmanirrahiim

In the name of Allah

Atta, Karaeng

Really, the Lord

Tabe' kipammoporang mama

I do apologize

Ri dallekang labbiritta,

In front of you

Ri sa'ri karatuanta
Beside your majesty

Riempoang matinggita

In your noble throne

From extract 7 above, the performer of Angngaru started his promise by using apology in "Tabe' kipammoporang mama" (I do apologize). Before the promising was pronounced, the speaker asked for apologies. The main intention was because the promising had a strict function in the relation between the King and the servant in the form of loyalty to do the best for the Kingdom, such as defending the Kingdom from enemies.

The fourth important speech act found in the text of Angngaru is commissive. This can be seen in the following three extracts:

Extract 8:

Inakke minne, Karaeng

Here I am, the Lord

Lambara' tatassa 'la'na Gowa

The hero from Gowa

Nakareppekangi sallang, Karaeng,

Pangngulu ri barugaya

Will break later, the Lord

The tip of my weapon in the arena

Nakatepokangi sallang, Karaeng

Pasorang attannga parang

Will break later, the Lord

The handle of the lance in the middle of the battlefield

Extract 9:

Punna sallang takammaya

If I break my promise later

Aruku ri dallekanta

As I promise in front of you

Pangkai jerakku

Mark my grave

Tinra' bate onjokku

Cross my name in the history

Pauang anak ri book

Tell to other next generation

Pasang anak tanjari

Advise to younger sons and daughters

Tumakkanaya karaeng

If I just can promise, the Lord

Natana rupai janjinna

But cannot do

Sikammajinne aruku ri dallekanta

That's my promise in front of you

Dasi-nadasi nani tarima panngaruk,

Salamak....

Hope God bless it. Congratulation.

Extract 10:

Punna sallang takammaya 
If later it is not proved

Aruku ri dallekanta

The promise that I have said now

Pangkai jerakku

Cross my grave

Tinraki bate onjokku

Stick my footpath

Pinrai arengku

Change my name

Piassalak jari-jariku

Curse my siblings

All of the extracts above (extract 8-10) showed the use of promising. The speaker promised to do his job properly. As expressed in extract 8, the speaker said, "Inakke minne, Karaeng, Lambara' tatassa 'la'na Gowa" (Here I am, the Lord, The hero from Gowa). The speaker promised in front of the King to defend the Kingdom in the war and that would not humiliate and disappoint the Kingdom. Therefore, he would sacrifice for that. Another form of promises can also be seen in extract 8 , where the speaker said, "Nakareppekangi sallang, Karaeng. Pangngulu ri barugaya" (Will break later, the Lord, the tip of my weapon in the arena). $\mathrm{He}$ promised to go in war and prepared to die on the battlefield. In fact, big consequences resulted if he broke his promise. The speaker said in extract 9, "Pangkai jerakku, Tinra' bate onjokku" (Mark my grave, Cross my name in the history). The speaker swore for big consequences for his words and expressions. In extract 11, the speaker also said, "pangkai jerakku, tinraki bate onjokku, pinrai arengku, piassalak jari-jariku" (Cross my grave, Stick my footpath, change my name, Curse my siblings). At the end he said "Salamak" (Hope God bless it), expecting that what he did would be successful and hopefully God bless it.

These are a form of promising, which should be consistent with the actions. If he failed to prove what he had said, he was subject to some actions such as marking his grave and changing his name in the story. In Makassar culture, the grave, the footpath, and the name are important representations for being a hero in life. Even the next sibling may get the risk for the failure of the promise for being cursed in their whole life.

\section{Discussion}

It can be seen that Angngaru has many functions in Makassar society. In the past times, it was used as the promises by the soldiers to the
King. Nowadays, since it is used in formal occasions to welcome the honorable guests, the main functions are now to show respects. In addition, the promise in the text of Angngaru can represent the principles of Makassar people. One of the ideas was the symbolism of badik, Makassar traditional weapon. The use of badik in the pronouncing of Angngaru means that the words uttered had a strict consequence. For Makassar people, badik is the symbol of brevity and high honor. Very seldom people used badik as it has great consequence for that. Badik is used to defend honor and shame. This is related to the concept of siri na pace (shame and compassion) which becomes the basic principle of Makassar people.

Based on the analysis of speech acts in nine extracts above, it was found that the speech act to "perform actions" and "to relate meaning and actions" (Austin, 1962; Searle, 1969) was also clearly used in the text of Angngaru. Based on the above extracts, several types of speech acts were found such as apologizing, requesting, asserting and promising. These types of speech acts were in line with Searle's taxonomy of speech acts.

The basic idea from this Angngaru is the strong idea between words and meaning. In Makassar culture, being consistent between what is said and what is acted is very important as reflected in the principle of Makassar people, siri na pacce (shame and compassion). The speech acts in the words and expressions of Angngaru revealed the important principles of Makassar people. In addition, the power of Makassar people was symbolized in some words and expressions of Angngaru. In Makassar society, the concept of sulapak appak (square) as noted by Iswary (2009: 103-104) is important which showed the characteristics of Makassar people. The concept of being barani (brave) and lambusuq (honest) can also be clearly seen in the expressed words of Angngaru.

\section{CONCLUSION}

This paper has discussed the significance of Angngaru as one part of Makassar traditional language usage. By observing the types of speech acts in Angngaru and investigating its functions, it is clearly seen that Angngaru has important roles in Makassar society. Angngaru is a form of promising conducted now in many types of ceremonies in Makassar society. As a part of 
cultural life, Angngaru is used to express appreciation and respects. It also becomes a symbol of strictness and the correspondence of actions and words in Makassar, the basic principles of Makassar people.

Several types of speech acts were found in Angngaru which represented the relationship between action and meaning. Those speech acts such as representatives, directives, expressives, and commissive were types of speech acts proposed by Searle (1969). These speech acts showed that languages used in Angngaru were depicting the strong relationship between the action and the expressed words which were also important in Makassar basic principle siri na pacce (shame and compassion). This principle brought the ideas that Makassar people are strict in their words and actions in order to preserve their honor (shame) and in order to build their compassion and solidarity among the community.

These findings are very beneficial input for readers in the field of literature and linguistic stu-

\section{REFERENCES}

Al-Shboul, Y. \& Maros, M. 2013. Condolences strategies by Jordanians to an obituary status update on facebook. GEMA Online Journal of Language Studies, 13(3), 151-162.

Amarien, N. 2010. Interlanguage pragmatics: A study of the refusal strategies of Indonesian speakers speaking English. TEFLIN Journal, 8(1), 1-12.

Austin, J. L. 1962. How to do things with words. Oxford: Clarendon Press.

Batch, K. \& Harnish, R.M. 1979. Linguistic communication and speech Acts. USA: The Massachussets Institute of Technology (MIT) Press.

Bonvillain, N. 1993. Language, culture, and communication: The meaning of messages. Englewood Cliffs: Prentice Hall.

Boxer, D. 1993. Social distance and speech behavior: The case of indirect complaints. Journal of Pragmatics, 19(2), 103-125.

Chabot, H. T. 1996. Kinship, status, and gender in South Celebes. Leiden: KITLV Press.

Chang, S.-Y., \& Liu, Y. 2016. From problem-orientedness to goal-orientedness: reconceptualizing communication strategies as forms of intra-mental and inter-mental mediation. System, 61, 43-54.

Duranti, A. 1997. Linguistic anthropology. New York: Cambridge University Press.

Graham, S. 2001. Negotiating gender: Calalai' in Bugis society. Murdoch University. http:// dies. This brings the important fact of language use in relation to culture in one particular society. Angngaru in Makassar society is one of the various forms of language expressions represented the culture and society. It is essential to explore this kind of fact to see the richness of language and culture all over the world. These findings show that studies on speech acts are essential in language and communication. Speech acts may represent the meanings and the words uttered. This indicated that studies on speech acts remain important and therefore, further studies on speech acts in different contexts of communicative situations need to be conducted.

\section{ACKNOWLEDGEMENT}

The author would like to thank to Arif, Rukanti, and Bahtiar Dg. Sanre for their participation in this study of Angngaru. Thank you to the reviewers who gave suggestions and comments on this article.

sshe.murdoch.edu.au/intersections/issue6/grah am.html, Accessed 11 March 2004.

Gunawan, A. 2013. Aru (Angngaru) sumpah setia para Tubarani (The Loyal Promise of the Brave People). http://gowa-negeri1001cerita. blogspot.com/2013. Accessed 26 July 2014.

Iswary, E. 2009. Pengajaran etika berbasis kearifan lokal Makassar di era globalisasi (The teaching of ethics based on local Makassar belief in the global era). Proceeding of the First International Conference on Language Education (ICOLE). Makassar: Language Center, the State University of Makassar (pp. 99-106).

Khairuddin, F. 2011. Aru Tubarani, Sumpahnya Kerajaan Gowa sebelum pergi perang (The Promise of Gowa Kingdom before War). http://m. kompasiana.com/post/read/368973/3/html. Accessed on 26 July 2014.

Kramsch, C. 1998. Language and culture. New York: Oxford University Press.

Krishnan, I. A., Ramalingam, S. J., Ching, S. H., \& Maruthai, E. 2018. The functions of communication strategies: an analysis of Chinese EFL learners' transactional practice. Journal of Language and Communication, 5(2), 151-159.

Levinson, S. C. 1983. Pragmatics. Cambridge: Cambridge University Press. 
Limpo, S. Y. L, Culla, A. S., \& Tika, Z. 1995. Profil sejarah budaya dan pemerintah Gowa (The Profiles of Culture and History of Gowa). Sungguminasa: Intisari.

Mahmud, M. 2017. Communicative styles of English students at the State University of Makassar. GEMA Online Journal of Language Studies, 17(1), 223-238.

Mestrie, R. 2000. Clearing the ground: Basic issues, concepts, and approaches. In Rajend Mesthrie, Joan Swam, Andrea Deumert, and William L. Leap (eds.). Introducing Sociolinguistics. Edinburg: Edinburg University Press.

Mey, J. L. 1993. Pragmatics: An Introduction. UK: Blackwell.

Milal, A.D. 2011. Indicators of the practice of power in language classrooms. The TEFLIN Journal, 22(1), 1-15.

Pawlak, M. 2015. Advanced learners' use of communication strategies in spontaneous language performance. In M. Pawlak \& E. Waniek-Klimczak (Eds.), Issues in teaching, learning, and testing speaking in a second language, second language learning, and teaching. Second language learning and teaching (pp. 121-141). Heidelberg, Berlin: Springer.

Pelras, C. 1996. The Bugis. Cambridge, Massachussets: Blackwell Publishers.

Sari, A. P. 2010. Female EFL learners' request realization in relation to their ethnic backgrounds. TEFLIN Journal, 21(1), 41-56.

Sattar, H. Q. A., Lah, S. C., \& Suleiman, R.R.R. 2011. Refusal strategies in English by Malay university students. GEMA Online Journal of Language Studies, 11(3), 69-81.

Saville-Troike, M. 1982. The Ethnography of communication: An Introduction. Oxford: Basil Blackwell.

Searle, J. 1969. Speech acts. Cambridge: Cambridge University Press.

Shcriffin, D. 1994. Approaches to discourse. UK: Blackwell.

Sifianou, M. 1992. Politeness Phenomena in England and Greece. Oxford: Clarendon Press.

Stranovska, E. Fraternova, Z., Munkova, D., \& Muglova, D. 2012. Politeness factors in requests formulated in the category with cognitive style. Studia Psychologica, 54(2), 111-124.

Syahri, I. 2013. Resemblance of indirectness in politeness of EFL learners'request realizations. Indonesian Journal of Applied Linguistics, 3(1), 148-165

Upadhyay, S. R. 2003. Nepali requestive acts: Linguistic indirectness and politeness reconsidered. Journal of Pragmatics, 35(1011), 1651-1677.

Wahid, S. 2008. Manusia Makassar (Makassar People). Makassar: Pustaka Refleksi.

Wajdi, M. 2009. Observing teachers and students' English: (Discourse analysis of the classroom). Proceeding of the First International Conference on Language Education (ICOLE). Makassar: Language Center, the State University of Makassar (pp. 218-228). 


\section{APPENDIX: \\ ARU TUBARANIA RI GOWA}

\section{Version 1:}

Anne nualleku, Karaeng

Akkanamak numammio

Angingak nulekok kayu

The King said, the Lord

I said, you heard

I am like the wind, you are like the leaves

Anne niallenu nikaraengang

Karaeng mako ikau

Atamak ikambe

Naia punna massongkang

Tamak lembarakkang

Punna maklembarakkang

Tamassongkang

Angingmako kilekok kayu

Naia sanik madidiaji nuirik

After being appointed as a King

Then you become a King

We are all servants

But, if we are bringing something on the head

We are not bringing by shoulders

If we are bringing by shoulders

We are bringing something on the head

You are like the wind and we are like the leaves

But, only those who turned yellow that you will get rid of.

Anne niallenu kikaraengang

Teai panganuammang

Tanu alleai jangang ri leranna

Tanukoccikiai bayao ribaka kampommang

Tanualleai kaluku sibatummang

Rappo sipaempang

Punna niak nukaeroki panganuammang

Nuballi sitaba nuballia

Nusambei sitaba nusambeia

Nupalaki sitaba nupalaka

Nakisareangko

Tanutappakaiai panganuammang

Ikambe tannakakdok bassimang

After being appointed as King

Only our body who serves

Our rights are not like that

You are not going to take chickens from the place they stay

You are not going to take our coconut or our palm fruit

If you want to have something from us

Buy those you can buy

Change those you can change

Ask something that you deserve

And we will give it to you

You cannot do whatever you like to us

Your iron will not hurt us

And you won't be hurt by our iron

\section{Version 2:}

Bismillahirahmanirrahiim

Atta, Karaeng

Tabe' kipammoporang mama

Ri dallekang labbiritta

Ri sa'ri karatuanta

Riempoang matinggita

In the name of Allah

Really, the Lord

I do apologize

In front of you

Beside your majesty

In your noble throne

Inakke mine, Karaeng

Lambara' tatassa 'la'na Gowa

Nakareppekangi sallang, Karaeng

Panngulu ri barugaya

Nakatepokangi sallang, Karaeng

Pasorang attannga parang

Here I am, the Lord

The hero from Gowa

Will break later, the Lord

The tip of my weapon in the arena

Will break later, the Lord

The handle of the lance in the middle of the battlefield

Inai-naiannamo sallang, Karaeng

Tamappatojengi-tojenga

Tamappiadaki adaka

Kusalagai sirinna

Kuisarak parallakkenna

Berangja kunipate'ba

Pangkulu kunisoeang

Although whoever, the Lord

Not justifying the right things

Not defying the culture and tradition

I will destroy his footpath

I will limit his movement

I am like a knife which is used to cut

Like the ax to swing

Ikau anging, Karaeng

Naikambe lekok kayu

Mirikko anging

Namarunang lekok kayu

Iya sani madidiyaji nurunang

You are like the wind, the Lord

I am like the leaves

Blow the wind

I am willing to go away with you

Although those of the yellow leaves which were destroyed

Ikau je'ne, Karaeng 
152 RETORIKA: Jurnal Bahasa, Sastra, dan Pengajarannya, Volume 12, Number 2, August 2019, p.p. 141-153

Naikambe batang mammayu

Solongko jekne

Namammayu batang kayu

Iya sani sompo bonangpi na kianyu

You are like the water, the Lord

I am like the log of wood

Flow the water

I am willing to drift with you

Although at the rising tide we drift

Ikau jarung, Karaeng

Naikambe bannang panjaik

Takleko jarung

Namminawang bannang panjaik

You are like the needle, the Lord

I am like the thread

Break it through the needle

Then I will tie your footpath

Iya sani lambusuppi nakontu tojeng

Makkanamamaki mae

Naikambe mappa'jari

Mannya'bbu mamaki mae, Karaeng

Naikambe mappakrupa

Punna sallang takammaya

Aruku ri dallekanta

Pangkai jerakku

Tinra' bate onjokku

Pauang anak ri boko

Pasang anak tanjari

Tumakkanaya karaeng

Natana rupai janjinna

Sikammajinne aruku ri dallekanta

Dasi-nadasi nani tarima panngaruku

Salamak...

Say, the Lord

I will do

Say, the Lord

I will serve

If I break my promise later

As I promise in front of you

Mark my grave

Cross my name in the history

Tell to other next generation

Advise to younger sons and daughters

If I just can promise, the Lord

But cannot do

That's my promise in front of you

Hope God bless it. Amen.

\section{Version 3:}

Tojeng, Karaeng

Tojeng-tojeng, Karaeng

Cinik-cinikmi sallang

Ata mattojeng-tojennu

Ata makbannang keboknu

Burakne tojenga

Katimbang laki-lakia
Bukkuruk tanikadoa

Jangang tanipakurrua

Tenaya tonrolok tanarakkai

Burakne nasampeangang

Barani nalanjo-lanjo

Truly, the Lord

It's exactly true, the Lord

See and watch later

Your servant who is true

Your servant who is loyal

The one who is truly masculine

A male grasshopper

A large turtledove which is not asked for

A rooster which is not talked with

There is no pole which is not be climbed

There is no man who is not avoided

There is no brave man who is to be afraid for

Tojeng, Karaeng

Tojeng-tojeng, Karaeng

I pantarak tompi sallang, Karaeng

Ri parang pattunggalengang

Ri bokdi pakbungdukannu

Nampa nucinik

Balembeng batang rappoa

Tonasak batang jambua

Truly, the Lord

Truly, the Lord

Later, the Lord

In the battlefield

In the battlefield

In the war

We will see it

The stick of areca nut

The sprout of guava stick

Inai-naianammo sallang, Karaeng

Tampateteko ri adak

Tampa empoko rikontu tojeng

Kupannepokangi sallang

Pasorang mattannga parang

Kupanreppekangi sallang

Panngulu ri barugaya

Whoever later, the Lord

Not put you in the proper custom

Not place you in the right matters

Will be broken

Will struck by the lance in the battlefield

Will be broken

The tip of the weapon in the middle of the arena

Version 4:

Sombangku! Napammoporam mamak jaidudu sombangku

Ri dallekang lakbirikna

Ri empoang matinggina

Ri sakri karatuanna

Satuli-tuli kanangku, Karaeng 
Panngainna laherekku Pappattojenna batengku My Lord, I asked for apologies In front of your majesty Above the high throne Beside your Kingdom I always say, the Lord My love for my place of birth My seriousness to my soul

Berangja kunipatekba Pangkuluk kunisoeang Ikatte anging, Karaeng Naikambe batang mammayu Ikatte jarung, Karaeng Naikambe banning panjaik I am like the big knife ready to cut The ax ready to swing You are like the wind, the Lord We are the leaves of the wood You are like the needle, the Lord We are the thread

Irikko anging

Namarunang lekok kayu

Solongko j eknek

Namammayu batang kayu

Takleko jarung

Namminawang banning panjaik

Blow the wind

Fall oh all of the leaves

Flow oh the water

Drift oh the leaves

Break through oh the needle

Then the sewing will follow

Makkanamamaki mae, Karaeng

Naikambe manngaukang

Mannyakbu mamaki mae

Naikambe makpakjari

Punna sallang takammaya

Aruku ri dallekanta

Pangkai jerakku

Tinraki bate onjokku

Pinrai arengku

Piassalakjari-jariku

Say, oh my Lord

And we will do what you want

If later it is not proved

The promise that I have said now

Cross my grave

Stick my footpath

Change my name

Curse my siblings
Pauangi anak ri boko

Pasangi ri anak tanjari

Tumakkanaya

Na taena nappakrupa

Sikammaji'nne aruku ri dallekanta karaeng

Dasi-nadasi na nitarima panngaruku

Lanri Allah Ta'ala

Inherit it to the next generation

Advise it to the next generation

That one can only say

But cannot prove

That is all my promise to you oh my majesty

I wish my willingness be approved

Because of Allah, Amen.

(pronounced by Maksud Dg. Siga, one of the performers of Angngaru)

(Limpo, Culla, \& Tika, 1995; Gunawan, 2013; Khairuddin, 2014) 